\title{
Identifying Freshwater Zooplankton Using DNA Barcoding Technique
}

\author{
Jie Ren \\ Oklahoma State University, Integrative Biology,501 Life Science W, Stillwater OK 74078 USA \\ (renj@okstate.edu)
}

DNA barcoding has emerged as a powerful approach for determining which species are present in an environment or sample. DNA barcoding has many advantages over traditional taxonomic approaches to identifying organisms, including use with any life stage, reliability, and no need for taxonomic expertise. The barcode library has expanded over the past decade to contain sequences of over 100,000 species, because the technique is affordable and easy to learn. DNA barcoding is increasingly common as course-embedded undergraduate research experiences. In this presentation, we described a DNA barcoding lab course offered as an honors add-on to our introductory animal biology class. The wet laboratory experience prepared freshmen for their own research projects and provides publication quality data useful in the research of many OSU faculty and as contributions to DNA barcoding libraries. We focused on identifying freshwater zooplankton, which are the basis for many aquatic food webs and common indicators of water quality. Students obtained plankton samples from scientists conducting research on invasive species and community structure, extracted DNA from individual zooplankton, PCR amplified the mitochondrial cytochrome oxidase subunit I (COI) gene, sent cleaned PCR products for sequencing, then searched a barcode library for the resulting sequences thus identifying the organisms.

Keywords: DNA barcoding, freshwater zooplankton, cytochrome oxidase subunit I (COI)gene

\section{Mission, Review Process \& Disclaimer}

The Association for Biology Laboratory Education (ABLE) was founded in 1979 to promote information exchange among university and college educators actively concerned with teaching biology in a laboratory setting. The focus of ABLE is to improve the undergraduate biology laboratory experience by promoting the development and dissemination of interesting, innovative, and reliable laboratory exercises. For more information about ABLE, please visit http:// www.ableweb.org/.

Advances in Biology Laboratory Education is the peer-reviewed publication of the conference of the Association for Biology Laboratory Education. Published articles and extended abstracts are evaluated and selected by a committee prior to presentation at the conference, peer-reviewed by participants at the conference, and edited by members of the ABLE Editorial Board. Published abstracts are evaluated and selected by a committee prior to presentation at the conference.

\section{Citing This Article}

Ren J. 2020. Identifying freshwater zooplankton using DNA barcoding technique. Article 50 In: McMahon K, editor. Advances in biology laboratory education. Volume 41. Publication of the 41st Conference of the Association for Biology Laboratory Education (ABLE). https://doi.org/10.37590/able.v41.abs50

Compilation (C) 2020 by the Association for Biology Laboratory Education, ISBN 1-890444-17-0. All rights reserved. No part of this publication may be reproduced, stored in a retrieval system, or transmitted, in any form or by any means, electronic, mechanical, photocopying, recording, or otherwise, without the prior written permission of the copyright owner.

ABLE strongly encourages individuals to use the exercises in this volume in their teaching program. If this exercise is used solely at one's own institution with no intent for profit, it is excluded from the preceding copyright restriction, unless otherwise noted on the copyright notice of the individual chapter in this volume. Proper credit to this publication must be included in your laboratory outline for each use; a sample citation is given above. 